\title{
Global Change and the Quaternary
}

\section{by Nathaniel Rutter and Hugues Faure}

Now that ICSU has established the International Geosphere-Biosphere Program, there should be much more interest in the Quaternary. The authors point out that INQUA and its national counterparts are the only interdisciplinary organizations with years of research experience on the effects of the global changes over the past two million years. (Ed.)

\section{The New ICSU Program}

At its 21st General Assembly at Berne, Switzerland, in September 1986, the International Council of Scientific Unions (ICSU) officially launched the International Geosphere-Biosphere Program: a Study of Global Change. The purpose of the IGBP is to advance our knowledge of the Earth as a living planet and a coupled system. The program will probably continue through to the end of the century and will interact closely with other major international efforts, such as the World Climate Program (ICSU-World Meteorological Organization) and the Man and Biosphere Program of Unesco.

The eentral aim of the IGBP is to describe and understand the interactive physical, chemical and biological processes that regulate the Earth's unique environment for life, the changes that are occurring in this system, and the manner in which they are influenced by human actions (Anon, 1986; Malone and Roederer, 1985). Although the program will concentrate mainly on basic research there will be almost immediate results that can be applied for the good of mankind. A deeper understanding of the coupled processes that govern the Earth's environment will provide the basis for more rational management of resources and will improve the forecasts of significant global change.

The focus and elements of the program suggested by ICSU's Ad Hoc Planning Group on Global Change were circulated to members of the ICSU family in May 1985. The view was that the IGBP should be a focused program of research directed at providing the body of knowledge needed to assess the near term - up to 100 year - future of the Earth. Such a program should be based on a restricted and well-planned series of observations, models, process studies, and experimental research. This should also include increased efforts to recover a much longer history of the Earth and its environment, from geological records and the records preserved in sediments (e.g. Fig. 1), trees and ice, for we recognize that changes on a wide spectrum of time scales, from years to hundreds of millions of years, are a significant feature of Earth history. Knowledge of the past is essential to the tasks of understanding the present and of predicting the future (Price, 1986).

The IGBP is envisaged as a program of cooperative efforts of varied disciplines - with biospheric interactions as the focus and discriminator in setting priorities and in establishing principal emphases. In concentrating on the interactive areas of the physical, chemical, and biological realms the program is truly focused and uniquely defined. Of course, it puts less emphasis on strictly disciplinary studies, which, although they have great strengths and momentum of their own, contribute less clearly to our understanding of the changing nature of the environment of life. The Global
Change program will complement these other less interdisciplinary programs and interact with them, while remaining an organizationally separate entity.

\section{The Role of Quaternarists}

Quaternarists obviously have a significant part to play in this program, and we must convince scientists in other disciplines, governing bodies, and our own colleagues of the importance of our participation for a successful program. Quaternary research, often in the framework of the International Union for Quaternary Research (INQUA), has contributed to the discovery and understanding of the various types of changes that have affected the Earth. Most factors that have influenced regional and giobal change have been directly or indirectly investigated by Quaternarists. Our interdisciplinary nature has commonly allowed us to exploit knowledge gathered by one discipline to answer questions or expand knowledge in another.

For example, in the realm of geophysies, magnetic reversals that are recorded in orientation of sediment particles have enabled us to establish Cenozoic chronologies and have aided in explaining biological changes linked to upper atmosphere ionization. Another finding of great importance is that the three major oribital parameters of the Earth have periodicities that are reflected in the isotopic composition of the oceans, and that influence major elimatic and sea level changes. Biological remains such as pollen and diatoms preserved in lake sediments not only suggest climatic changes at time intervals varying from a few hundred to thousands of years but also indicate other environmental conditions.

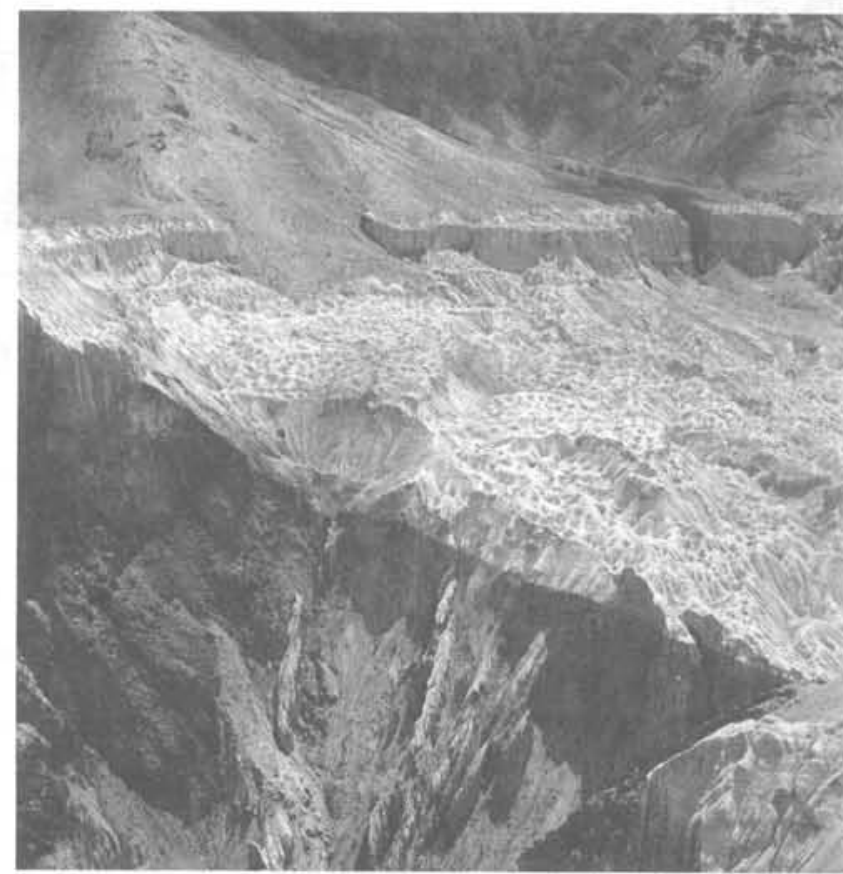

Figure 1: Quaternary lake sediments on steeply dipping Triassic flysch in the Ladakh suture zone near the famous Lama Yuru monastery, western Himalayas. Photo courtesy of A. Gansser. 
Although most Quaternary studies have been carried out in the Northern Hemisphere in the so-called developed countries, there has been a major increase in knowledge originating from other parts of the world. Governments are realizing the importance of Quaternary research in solving practical problems for the benefit of mankind. Nore education is needed, however, and the IGBP should help the cause. Our problem at this point is to make sure that Quaternarists are well represented in the planning and development of global change research programs and that we carry out a significant part of the research. This means world-wide participation, especially in developing countries where there is a paucity of Quaternary information and where adverse changes without adequate predictions can have disastrous effects.

As many of the papers in this issue of Episodes show, climatic change during the Quaternary has been influenced by astronomical frequencies, atmospheric carbon dioxide, global biomass, and ice volume. Of special importance are variations in sea-level and deep water temperature during climatic transitions. Other topics include fluctuations in the tropical mangroves of west Africa and the application of paleoecology to issues of global environmental change. Variations in global loess and eolian deposits, soils, paleohydrological conditions, and the use of ice-core records to detect climatic change during the last climatic cycle are also important. Furthermore, Quaternary observational data have important implications for the Earth's internal dynamic processes.

Quaternarists are contributing to a great variety of subjects related to global change. The momentum is there and must be sustained and expanded if the IGBP is to advance to its maximum potential towards improving the human condition.

INQUA 187. Special Session 28: Global Change. Organizers: N.W. Rutter (Canada) and H. Faure (France).
Prof. N.W. Rutter is a VicePresident of INQUA and Chairman of the Department of Geology, University of Alberta (Edmonton, Alberta, Canada T6G 2E3), Following geological assignments in Venezuela, Trinidad, Colombia and Turkey, he worked for the Geological Survey of Canada and the National Energy Board of Canada and continues his Quaternary research in western Canada, Argentina, Namibia and elsewhere.

Prof. H. Faure is the President of INQUA and is based at the Faculte des Sciences, (C.N.K.S. - Luminy, Case 907, F-13288 Marseille Cédex 9, France). His career includes 15 years mapping the geology of western Africa, and 5 years teaching at the University of Dakar in Senegal before joining the universities of Paris, and now Marseilles. Prof. Faure was profiled in the June 1984 issue of Episodes.

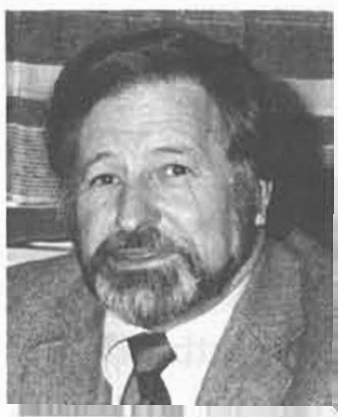

\section{References}

Anon, 1986. Global changes in the geosphere-biosphere: initial priorities for an IGBP. U.S. Committee for an IGBP, NRC Comnission on Physical Sciences, Mathematics and Resources, National Academy Press, washington, $91 \mathrm{p}$.

Mlalone, T.F. and Roederer, J.G., 1985. Global change. Cambridge University Press (for ICSU Press), Cambridge, $512 p$.

Price, R.A., 1986. Global change: geological processes, past and present. Episodes, v. 9, no. 2, p. 81-94. 